ANETA JARZĘBIŃSKA

Uniwersytet Szczeciński

\title{
Od diagnozy do towarzyszenia w żałobie - wsparcie rodzin z dzieckiem z wadą letalną
}

\begin{abstract}
Aneta Jarzębińska, Od diagnozy do towarzyszenia w żałobie - wsparcie rodzin $z$ dzieckiem $z$ wadq letalna [From the diagnosis to the accompanying in mourning - support from the families of children with lethal defect]. Interdyscyplinarne Konteksty Pedagogiki Specjalnej, nr 22, Poznań 2018. Pp. 375-391. Adam Mickiewicz University Press. ISSN 2300-391X. DOI: https:/ / doi.org/10.14746/ikps.2018.22.21

This article characterizes the interactions and institutions in which parents can receive support after their child has been diagnosed with a lethal defect. First and foremost parents need information and emotional support when making decision regarding their child. The primary source of the aforementioned elements is the hospital personnel and the perinatal hospice- that is if parents decide to contact it. If the child is born alive and discharged from the hospital then the parents require support during its treatment (which more often than not is identical with palliative care) and rehabilitation, even social rehabilitation. Children's hospices can offer many services in this particular matter. On each stage of the child's disease the contact with other parents of children with lethal defect is crucial. They can negate the feeling of isolation, give practical advice regarding the situation and most of all give hope that even though the prognosis is fatal some of the children lived.
\end{abstract}

KEY WORDS: child with a lethal defect, prenatal pedagogy, social support

W artykule podjęto próbę nakreślenia źródeł wsparcia dla rodziców dziecka z wadą letalną. Ukazano osoby i miejsca, które począwszy od okresu ciąży mogą służyć takim rodzicom rzetelną informacją o różnych aspektach choroby, być pomocne w zaplano- 
waniu porodu, usprawnić dostęp do świadczeń opieki zdrowotnej a przede wszystkim otoczyć rodzinę wsparciem emocjonalnym.

Inspiracją do podjęcia tytułowej tematyki była lektura blogów prowadzonych przez rodziców dzieci z wadami letalnymi (Zespołami: Edwardsa, Patau oraz Millera-Diekera). Autorka jednego z nich stwierdziła, że pod adresem dzieci ciężko chorych, nierokujących poprawy stanu zdrowia, najczęściej wybrzmiewają stwierdzenia takie jak: „,beznadziejny przypadek", , jemu to i tak nie pomoże”, ,szkoda czasu i pieniędzy", ,"została już tylko uporczywa terapia", , dla takich dzieci tylko hospicjum", „zajmuje miejsce dzieciom, które mają szanse wyzdrowieć". Tego rodzaju przekazy budują poczucie ogromnego osamotnienia rodziców, odbierają im siły do stawienia czoła chorobie, pozbawiają nadziei na dobrą przyszłość. Jednym zdaniem komplikują ich i tak już dramatyczną sytuację. Zarazem z lektury blogów wynikało, że rodzice dzieci z chorobami letalnymi nie zawsze zostają pozostawieni samym sobie, bo jak pisali $\mathrm{w}$ wirtualnych pamiętnikach, otrzymali wsparcie osób i instytucji, nawet jeśli początkowo nie zdawali sobie sprawy z istnienia pewnych możliwości.

\section{Specyfika sytuacji rodziców po zdiagnozowaniu u dziecka wady letalnej}

Ujętą w tytule nazwę "wada letalna” stosuje się na oznaczenie ciężkich nieprawidłowości rozwojowych o niepewnym lub złym rokowaniu. Wada letalna może prowadzić do: 1) poronienia obumarłego płodu, 2) przedwczesnego urodzenia martwego dziecka, 3) śmierci dziecka bezpośrednio po urodzeniu lub we wczesnym okresie niemowlęcym bez względu na zastosowane leczenie. Mimo postępu medycyny i możliwości zastosowania w leczeniu najnowocześniejszych osiągnięć biotechnologii i farmakologii, brakuje możliwości leczenia przyczynowego w wadach letalnych ${ }^{1}$.

1 J. Krzeszowiak, R. Śmigiel, Rola i zadania położnej jako członka zespołu sprawujacego opieke nad ciężarna pacjentka z rozpoznana wada letalna u płodu, „Pielęgniarstwo i Zdrowie Publiczne" 2016, 6, 1, s. 58. 
Każdego roku w Polsce rodzi się ponad 600 dzieci z wadą letalną ${ }^{2}$. Jeszcze więcej jest płodów $\mathrm{z}$ wadami letalnymi, zwłaszcza jeśli matka jest $w$ starszym wieku ${ }^{3}$. Dzięki rozwojowi technik diagnostyki prenatalnej dzielonych na dwie zasadnicze grupy: inwazyjne (ultrasonografia oraz badanie surowicy krwi ciężarnej kobiety) i nieinwazyjne, które polegają na pobraniu komórek dziecka prenatalnego celem ustalenia jego kariotypu i ewentualnej analizy DNA (jak amniopunkcja genetyczna, biopsja kosmówki, kordocenteza oraz fetoskopia) ${ }^{4}$ niektóre wady letalne można wstępnie rozpoznać począwszy od końca pierwszego trymestru trwania ciąży.

Widomość, że oczekiwane dziecko ma chorobę, która doprowadzi do jego przedwczesnej śmierci, być może jeszcze w okresie prenatalnym, jest dla rodziców niesłychanie obciążająca. Jak pisze Dorota Kornas-Biela, tego rodzaju informacja wywołuje u rodziców panikę, smutek, żal, niedowierzanie, zaprzeczanie, uczuciową labilność. Może się pojawić poczucie wstydu, winy i niesprawiedliwości oraz wiele innych skrajnie negatywnych przeżyćs. Rozpoznanie wady letalnej dziecka pociąga za sobą, jak to określa Renata Kleszcz-Szczyrba, zwielokrotnioną stratę. Pierwszą jest bezpowrotna utrata przez dziecko zdrowia, wtórną - utrata przez rodziców planów i nadziei, jakie wiązali z tym dzieckiem ${ }^{6}$.

${ }^{2}$ Liczbę żywo urodzonych dzieci z wadą letalną oszacowano w oparciu o założenie, że u 3\% dzieci żywo urodzonych występują WRWZAC, a 7\% z tej grupy to dzieci z wadami letalnymi; T. Dangel, Wady letalne u płodów i noworodków: opieka paliatywna jako alternatywa wobec eugenicznej aborcji, eugenicznego dzieciobójstwa i uporczywej terapii; http://www.hospicjum.waw.pl/phocadownload/Etyka/WadyLetalne UPlodowINoworodkow.pdf [dostęp: 2.05.2017].

${ }^{3} \mathrm{~Np}$. ryzyko wystąpienia u płodu zespołu Edwardsa wynosi 1:2484 dla kobiety 20- letniej, 1: 1456 dla 30-latki i 1:157 dla 40-latki; H. Kypros, P. Nicolaides, P. Węgrzyn, Badanie ultrasonograficzne między 11+0-13+6 tygodniem ciąży, Fetal Medicine Foundation, London 2004, s. 22.

${ }^{4}$ J. Skrzypczak, J. Kornacki, Ciąża o przebiegu niepowikłanym, [w:] Położnictwo. Podręcznik dla położnych i pielęgniarek, red. G.H. Bębrowicz, Warszawa 2005, s. 72-74.

${ }^{5}$ D. Kornas-Biela, Niepomyślna diagnoza prenatalna: dylemat rodziców, wyzwanie dla profesjonalistów, http://www.mp.pl/etyka/poczatki_zycia/39622,niepomyslna-diag noza-prenatalna-dylemat-rodzicow-wyzwanie-dla-profesjonalistow [dostęp: 2.05.2017].

${ }^{6}$ R. Kleszcz-Szczyrba, Witraże w ciemności czyli o przedwczesnej śmierci dziecka. Książka niosąca światto, Księgarnia św. Jacka, Katowice 2015, s. 78. 
Jeśli rodzice otrzymają rozpoznanie $\mathrm{w}$ okresie prenatalnym, dodatkowym obciążeniem będzie dla nich rozstrzyganie pomiędzy opcjami: przerwaniem ciąży, co jest $\mathrm{w}$ tej sytuacji ustawowo dopuszczalne, a jej kontynuacją. O ile dziecko urodzi się żywe, rodzice staną natomiast przed decyzjami typu: 1) resuscytacja dziecka vs jej niepodejmowanie; 2) intensywna terapia vs opieka paliatywna prowadzona $\mathrm{w}$ domu, na oddziale szpitalnym albo w ośrodku stacjonarnym; 3) korekcja chirurgiczna wady vs niepodejmowanie leczenia chirurgicznego; 4) śmierć $\mathrm{w}$ szpitalu vs śmierć w domu7 .

W konfrontacji z wielością problemów rodzice wymagają kompleksowego wsparcia. Na etapie ciąży pierwszoplanowa wydaje się wieloaspektowa informacja o chorobie, okazanie rodzicom zrozumienia oraz przygotowanie ich do podjęcia decyzji związanych z dzieckiem. Jeśli dziecko urodzi się żywe i zostanie wypisane do domu, pojawia się także konieczność wsparcia rodziców w jego pielęgnacji, leczeniu, rehabilitacji, a także podjęcie działań zapobiegających społecznemu wykluczeniu rodziny.

\section{Wsparcie udzielone przez personel placówek służby zdrowia}

Kobieta ciężarna, niezależnie od tego, czy jest ubezpieczona, czy nie, ma prawo do opieki zdrowotnej podczas ciąży, porodu i połogu, co regulują odpowiednie rozporządzenia, w szczególności rozporządzenie Ministra Zdrowia z 20 września 2012 r. w sprawie standardów postępowania medycznego przy udzielaniu świadczeń zdrowotnych z zakresu opieki okołoporodowej sprawowanej nad kobietą w okresie fizjologicznej ciąży, fizjologicznego porodu, połogu oraz opieki nad noworodkiem. Z kolei na mocy rozporządzenia Ministra Zdrowia z 6 listopada 2013 r. w sprawie świadczeń gwa-

7 T. Dangel, Decyzje dotyczace dzieci z nieuleczalnymi chorobami prowadzacymi do przedwczesnej śmierci w perinatologii, s. 3-6, http://www.ptb.org.pl/pdf/dangel_ neonatalna.pdf [dostęp: 20.09.2015]. 
rantowanych z zakresu programów zdrowotnych kobieta ciężarna może również skorzystać z "Programu badań prenatalnych" pod warunkiem, że spełnia przynajmniej jedno z wyznaczonych w tym programie kryteriów ${ }^{8}$. Gdy ciąża i poród są powikłane oraz gdy występuje niepowodzenie położnicze, postępowania wobec kobiety określa Rozporządzenie Ministra Zdrowia z z dnia 9 listopada 2015 r. w sprawie standardów postępowania medycznego przy udzielaniu świadczeń zdrowotnych w dziedzinie położnictwa i ginekologii z zakresu okołoporodowej opieki położniczo-ginekologicznej, sprawowanej nad kobietą w okresie ciąży, porodu, połogu, w przypadkach występowania określonych powikłań oraz opieki nad kobietą w sytuacji niepowodzeń położniczych.

W optymalnych warunkach w rozpoznaniu wady letalnej dziecka i procesach decyzyjnych dotyczących postępowania po postawieniu diagnozy bierze udział wielu specjalistów z zakresu nauk medycznych: lekarze położnicy prowadzący ciążę i diagnostykę prenatalną, genetycy kliniczni, specjaliści wykonujący ECHO serca płodu, chirurdzy dziecięcy, neonatolodzy, a także specjaliści medycyny paliatywnej, którzy są zaangażowani w opiekę nad dzieckiem już po jego urodzeniu ${ }^{9}$. Zadaniem tych osób jest właściwe rozpoznanie choroby i udzielenie rodzicom możliwie kompletnej informacji. Powinna ona zawierać wiedzę o objawach chorobowych, rokowaniu, perspektywach leczenia i rehabilitacji dziecka. Ponadto należy z rodzicami omówić ich plany prokreacyjne ${ }^{10}$.

8 1) wiek matki powyżej 35 lat; 2) wystąpienie w poprzedniej ciąży aberracji chromosomowej; 3) stwierdzenie wystąpienia strukturalnych aberracji chromosomowych u ciężarnej lub u ojca dziecka; 4) stwierdzenie znacznie większego ryzyka urodzenia dziecka dotkniętego chorobą uwarunkowaną monogenetycznie lub wieloczynnikową; 5) stwierdzenie w czasie ciąży nieprawidłowego wyniku badania USG i/lub badań biochemicznych wskazujących na zwiększone ryzyko aberracji chromosomowej lub wady płodu (Zarządzenie Nr 66/2007/DSOZ, załącznik nr 5).

9 J. Krzeszowiak, R. Śmigiel, op. cit., s. 57.

10 A. Libera, Psychologiczny aspekt poronien, [w:] Psychologia w położnictwie i ginekologii, red. M. Makara-Studzińska, G. Iwanowicz-Palus, Wydawnictwo Lekarskie PZWL, Warszawa 2009. 
Ważna jest nie tylko treść informacji przekazanych przez personel medyczny, ale także ich forma. Rodzice potrzebują zrozumienia dla przeżywanych uczuć i cierpliwego wysłuchania. Niestosowne jest używanie w ich obecności określeń na nazwanie dziecka, które choć funkcjonują w nomenklaturze medycznej, są niepersonalistyczne. W rozmowie z rodzicami, których dziecko żyje, należy wyeksponować aspekty, które stanowią podstawę budowania racjonalnej nadziei (dalekiej od przedstawiania iluzji wyleczenia dziecka). Ostatecznie, co podkreśla Jadwiga Łuczak-Wawrzyniak, udzielanie rodzicom informacji o chorobie nie jest, a przynajmniej nie powinno być zwykłą rozmową, tylko sztuką ${ }^{11}$.

Kolejny raz badaliśmy córkę podczas umówionej na wrzesień wizyty w poradni przyklinicznej w Szpitalu Uniwersyteckim. Przyjęła nas wspaniała Pani Doktor. Ta sama, od której się dowiedziałam o chorobie córeczki. Dziwne, piszę o niej, że jest wspaniała a przecież to od niej usłyszałam informację, która sprawiła mi w życiu największy ból. Także i tym razem była pełna empatii i zrozumienia. Tak pięknie badała naszą córkę. Poczułam, że choć nie chciała nas nastawiać optymistycznie, dawała odczuć, że według niej córka ma się całkiem dobrze. I jeszcze kilka ciepłych słów pod naszym adresem: jakimi jesteśmy wspaniałymi rodzicami, dzięki którym trochę lepiej się nam funkcjonuje ${ }^{12}$.

Rodzice mogą również liczyć na wsparcie psychologa, w tym zatrudnionego w szpitalu. Niestety, z badań wynika, że najczęściej nie wiedzą o takiej, teoretycznej nawet możliwości, wobec czego nasuwa się wniosek, że rola psychologa nie powinna ograniczać się do oczekiwania, aż rodzice sami zgłoszą się do gabinetu, ale raczej

11 J. Łuczak-Wawrzyniak, Leczenie jest sztuka- na pod-stawie wybranych obszarów działalności szpitala ginekologiczno-położniczego, „Ginekologia Polska” 2002, nr 73 (10), s. $884-887$.

12 Cytat, podobnie jak kolejne, pochodzi z bloga poświęconemu dziecku z wadą letalną. W celu osłonięcia tożsamości Autorów blogów w artykule nie podano ich nazw ani adresów internetowych. W tym samym celu nieznacznie przeredagowano przytoczone fragmenty wpisów. 
na inicjowaniu kontaktu i przedstawianiu możliwości opieki psychologicznej ${ }^{13}$.

W złożonej psychologicznie sytuacji, w jaką wchodzą rodzice po rozpoznaniu u dziecka wady letalnej, wsparcie udzielone przez personel szpitalny jest jednak niewystarczające. Oprócz informacji rodzice potrzebują wsparcia $\mathrm{w}$ formie wartościującej, instrumentalnej, a przede wszystkim emocjonalnej oraz duchowej ${ }^{14}$. Realizacja tego założenia jest możliwa, o ile czerpią równocześnie z kilku źródeł wsparcia.

\section{Rodzice źródłem wzajemnego wsparcia}

W konfrontacji z informacją o letalnej chorobie dziecka pierwszym i podstawowym źródłem wsparcia, na początek głównie emocjonalnego, powinni być dla siebie małżonkowie/partnerzy. Założenie bywa jednak problematyczne $\mathrm{w}$ realizacji z uwagi na zróżnicowanie przeżyć i reakcji rodziców. Według Doroty Kornas-Bieli kobieta, jako bardziej zaangażowana w sytuację i wykazująca silniejszą ekspresję emocjonalną, ma często poczucie niezrozumienia przez ojca dziecka, opuszczenia oraz niedocenienia wagi sytuacji ${ }^{15}$. Postawa partnera, różna od własnej, może wywoływać w kobiecie gniew, może ją ona interpretować jako przejaw małej troski mężczyzny o dziecko lub odrzucenia jej samej ${ }^{16}$.

Warunkiem wzajemnego wspierania się rodziców jest jednolite stanowisko odnośnie dalszego losu ciąży: czy chcą ją kontynuować, czy, jak dopuszcza obowiązujące prawo, decydują się na jej prze-

13 A. Kopeć i in., Hospitalizacja dziecka w Oddziale Intensywnej Terapii Noworodka doświadczenia rodziców, „Current Problems of Psychiatry” 2016, nr 17(1), s. 28.

${ }^{14}$ Klasyfikacja form wsparcia wg. S. Kawuli, Wsparcie społeczne-kluczowy wymiar pedagogiki społecznej. Głos w dyskusji, "Problemy Opiekuńczo Wychowawcze” 1996, nr 1.

15 D. Kornas-Biela, op. cit.

16 J. Makselon, Typologia i dynamika żałoby, [w:] Człowiek nieuleczalnie chory, red. B. Block, W. Otrębski, WNS KUL, Lublin 1997. 
rwanie. Nie powinno być mowy o arbitralnym podsuwaniu rozstrzygnięcia, w oderwaniu od argumentacji emocjonalnej, bez uszanowania uznawanego światopoglądu, bo może to być zarzewiem późniejszego obwiniania partnera za podjętą decyzję.

Po narodzinach dziecka znaczenia nabiera dzielenie obowiązków związanych z jego obecnością zwłaszcza, że obok powinności, które można uznać za standardowe w opiece nad noworodkiem, dają o sobie znać te, które są konsekwencją choroby, jak np. karmienie z użyciem sondy czy przezskórnej gastrostomii endoskopowej (tzw. peg). Pojawia się też obciążenie psychiczne wynikające ze świadomości, że stan dziecka może w każdej chwili i bez zapowiedzi gwałtownie się pogorszyć, bo taka jest specyfika wad letalnych. Jeśli w rodzinie obecne są inne dzieci, one także wymagają uwagi. Pomimo obecności chorego rodzeństwa, ich potrzeby muszą być spełnione. W opisanych okolicznościach wsparcie udzielane przez partnera jest nie do przecenienia.

W sobotę u synka pojawiła się gorączka, biegunka i wymioty. Ja od rana do wieczora pracowałam, więc na posterunku został Tata. Sam z dwoma synami, z których jeden wymagał nieustannego przewijania, przebierania, karmienia marchewkami z ryżem i pojenia elektrolitami, a drugi domagał się ciągłego i aktywnego uczestnictwa w zabawach. Tata z pewnością się nie nudził. Na szczęście jest najlepszym Tatą na świecie i z chłopakami radzi sobie doskonale, więc wyszedł z tego boju zwycięsko.

Rodzice mogą być dla siebie wsparciem w procesie oczekiwania na dziecko z wadą letalną i jego wychowania zwłaszcza, jeśli wypracują pewne strategie radzenia sobie. Jedną $z$ bardziej interesujących, jaką udało się zidentyfikować dzięki lekturze treści blogów, jest potraktowanie choroby dziecka metaforycznie jako podróży, którą odbywa się z przeświadczeniem, że choć jest trudna i prowadzi bliżej nieokreślonymi szlakami, przyniesie pozytywne zmiany.

Od pierwszych miesięcy życia zabieraliśmy nasze dzieci w podróże. Tym razem nieoczekiwanie stało się odwrotnie ponieważ to synek zaprosił nas na wyprawę i to $\mathrm{w}$ nieznane. Choć nie $\mathrm{z}$ otwartymi ramio- 
nami i bez uśmiechu na ustach, przyjęliśmy to zaproszenie. I oto jesteśmy razem $w$ drodze. Jednak tym razem nasza podróż ma dużo głębszy wymiar, niż zwykle. Sfera niematerialna, która była w naszych podróżach zawsze jest $\mathrm{w}$ jakimś stopniu obecna, tym razem wysunęła się na pierwszy plan. Tym razem właściwie nie wiemy, dokąd zmierzamy. Wiemy co najwyżej, że to trudna drogą. Jestem jednak przekonana, że często na końcu takich dróg znajduje się miejsce, w którym nie jest się w stanie powiedzieć ani słowa. Bynajmniej nie tylko z powodu zmęczenia ale z zachwytu. Myślę sobie, że z tego wszystkiego coś pozytywnego musi wyniknąć.

\section{Wsparcie rodziny przez hospicjum perinatalne}

Względnie nową propozycją wsparcia rodziców dzieci z wadą letalną jest oferta hospicjów perinatalnych, z której mogą korzystać nieodpłatnie począwszy od prenatalnego rozpoznania wady do ukończenia przez dziecko 28. dnia życia17. Pierwsza w kraju placówka tego typu powstała w Warszawie, w czerwcu 2006 r., kiedy przy Fundacji Warszawskie Hospicjum dla Dzieci otworzono poradnię USG ${ }^{18}$. Obecnie w kraju istnieje 16 placówek, najczęściej wydzielonych w strukturze hospicjów dla dzieci lub szpitali klinicznych, oferujących w różnym zakresie perinatalną opiekę hospicyjną. Zlokalizowane są w: Krakowie (trzy), we Wrocławiu (dwie) oraz w Warszawie, Tychach, Łodzi, Białymstoku, Gdańsku, Poznaniu, Lublinie, Opolu, Rzeszowie, Katowicach i w Bydgoszczy (po jednej).

Aktualnie brak jednolitego modelu funkcjonowania hospicjów perinatalnych. Najpełniej rozwinięta wydaje się koncepcja wsparcia wypracowana przez hospicjum perinatalne przy Fundacji Warszawskie Hospicjum dla Dzieci, która z resztą dzięki prowadzonym

17 Szerzej o hospicjach perinatalnych w artykule autorki pt. Hospicjum perinatalne - miejsce wsparcia dla rodziny $z$ dzieckiem z wada letalna, "Problemy Opiekuńczo-Wychowawcze" 2016, nr 8.

18 J. Szymkiewicz-Dangel, Perinatalna opieka paliatywna- czy możliwa jest wspótpraca położników i neonatologów z hospicjami domowymi dla dzieci? , „Opieka Paliatywna nad Dziećmi" 2007, t. 15, s. 27. 
szkoleniom dla lekarzy i psychologów z innych ośrodków stopniowo upowszechniana jest $\mathrm{w}$ całym kraju ${ }^{19}$. Obejmuje ona następujące etapy wsparcia rodziny $\mathrm{z}$ dzieckiem $\mathrm{z}$ wadą letalną:

1. Konsultacja $\mathrm{z}$ lekarzem konsultantem poradni USG przy hospicjum.

2. Dalsze konsultacje specjalistyczne, w tym głownie psychologiczna i genetyczna; badania prenatalne inwazyjne oraz spotkanie z innymi rodzicami, którzy zdecydowali się na wsparcie przez hospicjum perinatalne.

3. O ile rodzice zdecydują się na przerwanie ciąży, pacjentka ma możliwość skorzystania z konsultacji psychologicznej i dołączenia do grupy wsparcia. Jeśli natomiast rodzice postanowią kontynuować ciążę, w ramach oferty hospicjum proponuje się im perinatalną opiekę paliatywną obejmującą (w zależności od diagnozy):

- kontrolę USG/ECHO płodu w poradni przy hospicjum,

- opiekę położniczą w poradni patologii ciąży,

- zorganizowane przez lekarza hospicjum spotkania rodziców $\mathrm{z}$ lekarzem położnikiem $\mathrm{w}$ celu ustalenia postępowania okołoporodowego,

- zorganizowanie spotkania rodziców z lekarzem neonatologiem $w$ celu omówienia postępowania $\mathrm{z}$ noworodkiem ${ }^{20}$.

Ważnym aspektem wsparcia udzielanego przez hospicjum perinatalne jest praca położnej. Do jej zadań należy przede wszystkim przygotowanie rodziców do porodu i prowadzenie przez okres ciąży. Rolą położnej jest również ukierunkowanie rodziców na ewentualność narodzin martwego bądź umierającego dziecka i omówienie sposobu pożegnania się z nim (np. przygotowując specjalne ubranko, wypełniając obrzędy zgodne z wyznawaną przez rodziców religią, robiąc zdjęcia w czasie i po porodzie)21;

${ }^{19}$ Hospicja perinatalne- placówki poza systemem, http://info.wiara.pl/doc/3506371. Hospicja-perinatalne-placowki-poza-systemem [dostęp: 19.02.2017].

20 D. Maksiewicz, T. Dangel, II Ogólnopolska Konferencja Hospicjów Perinatalnych, „Hospicjum” 2015, nr 2 (72), s. 13, file:/ / C:/Users/aneta/Downloads/informatorhospicjum-nr72-czerwiec-2015\%20(1).pdf [dostęp: 9.05.2017].

21 J. Krzeszowiak, R. Śmigiel, op. cit. 
4. O ile dziecko urodzi się żywe, zostaje umieszczone na oddziale neonatologicznym. Tam otrzymuje opiekę paliatywną nastawioną na zapewnienie komfortu i ochronę przed uporczywą terapią. Równolegle jego rodzice utrzymują kontakt z psychologiem hospicjum perinatalnego.

5. Jeżeli dziecko przeżyje na oddziale neonatologicznym kilka kolejnych dni i jego stan na to pozwala, może zostać skierowane przez lekarza neonatologa do hospicjum domowego ${ }^{22}$. Wówczas rodzina może liczyć na pediatryczną opiekę paliatywną, która obejmuje:

- świadczenia opieki zdrowotnej udzielane przez lekarzy i pielęgniarki,

- leczenie bólu i innych objawów somatycznych zgodnie z aktualnymi wytycznymi i wiedzą medyczną,

- rehabilitacje w przypadku stwierdzenia przez lekarza hospicjum istniejących ku temu wskazań medycznych,

- zapobieganie powikłaniom,

- badania zlecone przez lekarza hospicjum domowego,

- ordynację leków,

- bezpłatne wypożyczanie niezbędnego sprzętu medycznego,

- opiekę psychologiczną nad pacjentem i jego rodziną, w tym wsparcie w żałobie,

- wsparcie socjalne obejmujące m.in. wykonywanie prac remontowo-adaptacyjnych mieszkań, pomoc w organizowaniu i finansowaniu wyjazdów wypoczynkowych oraz wsparcie duchowe, którego kluczowym elementem jest budowanie nadziei, również przez odniesienie do wyznawanej religii a także pomoc $\mathrm{w}$ zaakceptowaniu faktu choroby, a najczęściej również i śmierci dziecka ${ }^{23}$.

22 Fundacja Warszawskie Hospicjum dla Dzieci, Hospicjum perinatalne, Warszawa 2016, s. 8, file:///C:/Users/aneta/Desktop/1037_hospicjum-perinatalne-mate rialy-informacyjne.pdf [dostęp: 29.04.2017].

23 A. Korzeniewska-Eksterowicz i in. (oprac.), Standardy prowadzenia pediatrycznej opieki paliatywnej Ogólnopolskiego Forum Pediatrycznej Opieki Paliatywnej, s. 2-3, http://ofpop.pl/wp-content/themes/inove/img/standardy-ofpop-2016.pdf [dostęp: 29.04.2017]. 
Zgodnie z modelem propagowanym przez hospicjum warszawskie, $\mathrm{w}$ razie śmierci dziecka pracownicy hospicjum: lekarz i pielęgniarka (a także ksiądz, jeśli rodzice życzą sobie jego obecności), starają się dotrzeć do domu pacjenta jak najszybciej. Na miejscu okazują rodzicom współczucie a poprzez stwierdzenia, że dobrze opiekowali się swoim dzieckiem, że zrobili wszystko, co było możliwe, dają także wsparcie wartościujące. Może również mieć miejsce wspólna modlitwa, która jest wyrazem wsparcia duchowego. Następnie personel hospicjum pomaga rodzicom w kwestiach formalnych: lekarz wypełnia kartę zgonu, a pracownik socjalny załatwia $\mathrm{z}$ rodzicami sprawy urzędowe. Ponadto pracownicy hospicjum towarzyszą rodzicom w pogrzebie, a później zapraszają ich do grupy wsparcia w żałobie ${ }^{24}$.

Dość szybko skontaktowałam się z hospicjum domowym. Prosząc o pomoc myślałam przede wszystkim o sprawach zasadniczych o sprzęcie, który będzie mi potrzebny, aby bezpiecznie móc się opiekować córeczką w domu. Odzew hospicjum był natychmiastowy. Już kolejnego dnia pani doktor i pani pieleggniarka przyjechały do szpitala, aby nas poznać. Przyznam, że nie spodziewałam się, że nawiązanie tego kontaktu, aż tak mi pomoże i to przede wszystkim psychicznie. Poczulam się silna i bezpieczna. Po tym spotkaniu utwierdziłam się w przekonaniu, że nasza decyzja o zabraniu córeczki do domu była jedyną słuszną. Nazajutrz pani pielęgniarka przywiozła nam $\mathrm{z}$ hospicjum do domu: koncentrator tlenu oraz strzykawki i sondy potrzebne do karmienia. Nasz dom otoczony jest teraz nie tylko oczekiwaną pomocą medyczną i profesjonalizmem ale także spokojem, serdecznością i dobrym słowem.

\section{Wsparcie otrzymane od innych rodziców dzieci $\mathrm{z}$ wadą letalną}

Kiedy dziecko zapada na rzadką chorobę, zwykle trudno we własnym otoczeniu zidentyfikować osoby w podobnej sytuacji ży-

24 Szpital to nie jest dobre miejsce dla dzieci. Rozmowa z Tomaszem Dangelem, „Hospicjum” 2011, nr 1 (55), s. 26, file:/ / C:/Users/aneta/Downloads/informatorhospicjum-nr55-marzec-2011.pdf [dostęp: 21.02.2017]. 
ciowej. Tymczasem kontakt $\mathrm{z}$ takimi osobami mógłby zniwelować poczucie odosobnienia, zaowocować wymianą informacji i doświadczeń, uzmysłowić, na co się ma wpływ, a czego nie można zmienić. Badania potwierdzają, że rodzice ciężko chorych noworodków doceniają rolę, jaką $\mathrm{w}$ uporaniu się z trudną sytuacją mogą odegrać ludzie mający podobne przeżycia ${ }^{25}$.

Kontakt do innych rodzin $\mathrm{z}$ dzieckiem $\mathrm{z}$ wadą letalną rodzice mogą otrzymać $w$ ramach wsparcia udzielanego przez hospicjum, już na etapie ciąży. Sposobnością do spotkań z innymi rodzinami $z$ chorym dzieckiem są także organizowane i finansowane przez hospicja turnusy wypoczynkowe. Kontakty twarzą w twarz są dla rodziców nie tylko cennym źródłem wiedzy o różnych aspektach choroby, ale przede wszystkim podstawą do budowania nadziei, ponieważ przekonują się, że są dzieci, które żyją wbrew fatalnym rokowaniom i opanowały umiejętności będące swego rodzaju kamieniami milowymi.

$\mathrm{W}$ czerwcu nawiązaliśmy kontakt $\mathrm{z}$ kolejną rodziną $\mathrm{z}$ dzieckiem z Edwardsem. Naturalnie zdecydowaliśmy się na spotkanie. Doszło do kolejnego spotkania „na szczycie”. Przekonałam się, że dzieci z tą samą chorobą mogą rozwijać się zupełnie różnie. Tamta dziewczynka wspaniale trzyma pion i chodzi - co prawda na paluszkach - ale jest to olbrzymi sukces jej i rodziców. Nasza Księżniczka też przyglądała się kolejnej siostrzyczce w chorobie. Z kolei we wrześniu mieliśmy długo oczekiwany wyjazd nad Bałtyk. Dużo jodu, idealny okres na poprawę dróg oddechowych ale ważniejsze było zapoznanie się z innymi chorymi dziećmi. A już najważniejsze okazało się zapoznanie Małgosi najstarszego Edwardsiaka, jakiego znam. Z tego miejsca chce pozdrowić i przesłać całusy dla wszystkich.

W rozważaniach skoncentrowanych wokół zagadnienia wsparcia rodziców dzieci z wadą letalną nie sposób pominąć internetu. Jest on popularnym źródłem informacji o zdrowiu i chorobie, $\mathrm{w}$ tym także o dzieciach $\mathrm{z}$ wadą letalną. $\mathrm{Z}$ rodzicami takich dzieci

25 A. Kopeć i in., Hospitalizacja dziecka w Oddziale Intensywnej Terapii Noworodka doświadczenia rodziców, "Current Problems of Psychiatry” 2016, nr 17 (1), s. 28. 
można nawiązać kontakt w ramach wirtualnych grup wsparcia istniejących na portalach społecznościowych (np. grupa Mali Giganci z Zespołem Edwardsa), forów dyskusyjnych (w tym działających $\mathrm{w}$ ramach stron stowarzyszen, np. Stowarzyszenia na Rzecz Dzieci z Rzadkimi Chorobami Genetycznymi i Ich Rodzin "Wspólnie”) czy prowadzonych przez rodziców blogów.

W wirtualnie powstałych grupach, choć nie są one wolne od zastrzeżeń, występują unikatowe warunki, które ułatwiają ich członkom ujawnianie osobistych doświadczeń i rozwój wspierających relacji. Jednymi z ważniejszych są: możliwość komunikowania się z pominięciem granic przestrzennych i o każdej porze, wrażenie anonimowości oraz brak podziałów wynikających z wieku, płci, wyglądu czy wykształcenia ${ }^{26}$. Swoje zalety ma również forma pisana, na jakiej opiera się komunikacja on-line. Proces spisywania myśli, emocji i doświadczeń - pisze Małgorzata Wysocka-Pleczyk - jest korzystny z terapeutycznego punktu widzenia - poprawia bowiem samopoczucie i nastrój27. Warto podkreślić, że kontakty nawiązane w sieci są niekiedy przenoszone poza nią, obejmując takie formy jak rozmowy telefoniczne czy nawet osobiste spotkania ${ }^{28}$.

\section{Podsumowanie}

Po rozpoznaniu u dziecka wady letalnej rodzina wchodzi w niezwykle trudną sytuację psychospołeczną. Rodzice dowiadują się, że wskutek braku możliwości leczenia przyczynowego choroby

26 Szerzej o własnościach sieci sprzyjających komunikacji w pracy M. Grabowskiej, Wartość dodana Internetu na przykładzie internetowych grup wsparcia, [w:] Wielka sieć. E-seje z socjologii Internetu, red. J. Kurczewski, Trio, Warszawa 2006, s. 270-273.

27 M. Wysocka-Pleczyk, Grupy wsparcia online jako nowa forma pomocy w zmaganiu się z chorobą, „Hygeia Public Health” 2012, 47 (4), s. 394.

28 Opisany kierunek autorka zaobserwowała badając uczestników dyskusji na forum poświęcone dzieciom z letalnym Zespołem Edwardsa; A. Jarzębińska, Wsparcie społeczne w interakcjach rodziców dzieci z Zespołem Edwardsa - użytkowników forum internetowego, Wydawnictwo US, Szczecin 2017, s. 142-144. 
ich dziecko umrze przedwcześnie. Mimo tragicznej diagnozy, wielu z nich decyduje się podjąć starania, aby życie dziecka, choć krótkie, było dobre ( $\mathrm{w}$ rozumieniu wolne od bólu i uporczywej terapii, w otoczeniu kochających osób). W realizacji tego zamierzenia rodzice mogą jednak czuć się niekompetentni i przeciążeni. Wymagają wsparcia w zasadzie we wszystkich jego formach i z wielu źródeł jednocześnie.

Na początek rodzice potrzebują zwłaszcza wsparcia specjalistów z zakresu nauk medycznych: lekarzy położników prowadzących ciążę i diagnostykę prenatalną, genetyków, chirurgów dziecięcych, neonatologów. Przekazując rodzicom wiedzę o różnych aspektach choroby, wspierają ich oni w podjęciu decyzji związanych z dzieckiem. Zapewniają opiekę medyczną ciężarnej kobiecie i dziecku. Po porodzie rodzina może zostać objęta opieką hospicjum domowego, które zapewnia wsparcie w różnych formach, także po śmierci dziecka. Dopełnieniem źródeł wsparcia dla rodziców $\mathrm{z}$ dzieckiem $\mathrm{z}$ wadą letalną mogą być inne rodziny $\mathrm{z}$ chorym dzieckiem. W tego rodzaju interakcjach możliwa jest wymiana informacji, instruktarz, wsparcie wartościujące i emocjonalne oraz - co wydaje się sprawą zasadniczą - budowanie nadziei, że mimo fatalnych rokowań, niektóre dzieci z wadą letalną żyją i zdobywają kolejne umiejętności rozwojowe.

\section{Bibliografia}

Dangel T., Decyzje dotyczace dzieci z nieuleczalnymi chorobami prowadzacymi do przedwczesnej śmierci w perinatologii, http://www.ptb.org.pl/pdf/dangel_neonatal na.pdf [dostęp: 20.09.2015].

Dangel T., Wady letalne u płodów i noworodków: opieka paliatywna jako alternatywa wobec eugenicznej aborcji, eugenicznego dzieciobójstwa i uporczywej terapii; http://www. hospicjum.waw.pl/phocadownload/Etyka/WadyLetalneUPlodowINoworod kow.pdf [dostęp: 20.05.2017].

Fundacja Warszawskie Hospicjum dla Dzieci, Hospicjum perinatalne, Warszawa 2016, file:// C:/Users/aneta/Desktop/1037_hospicjum-perinatalne-materialy-infor macyjne.pdf [dostęp: 29.04.2017]. 
Grabowska M., Wartość dodana Internetu na przykładzie internetowych grup wsparcia, [w:] Wielka sieć. E-seje z socjologii Internetu, red. J. Kurczewski, Trio, Warszawa 2006.

Hospicja perinatalne- placówki poza systemem, http://info.wiara.pl/doc/3506371.Hos picja-perinatalne-placowki-poza-systemem [dostęp: 19.02.2017].

Jarzębińska A., Hospicjum perinatalne - miejsce wsparcia dla rodziny $z$ dzieckiem $z$ wada letalna, „Problemy Opiekuńczo Wychowawcze” 2016, nr 8.

Jarzębińska A., Wsparcie społeczne w interakcjach rodziców dzieci z Zespołem Edwardsa użytkowników forum internetowego, Wydawnictwo US, Szczecin, 2017.

Kawula S., Wsparcie społeczne- kluczowy wymiar pedagogiki społecznej. Głos w dyskusji, „Problemy Opiekuńczo Wychowawcze” 1996 nr 1.

Kleszcz-Szczyrba R., Witraże w ciemności czyli o przedwczesnej śmierci dziecka. Książka niosaca światło, Księgarnia św. Jacka, Katowice 2015.

Kopeć A. i in., Hospitalizacja dziecka w Oddziale Intensywnej Terapii Noworodka - doświadczenia rodziców, „Current Problems of Psychiatry” 2016, nr 17 (1).

Kornas-Biela D., Niepomyślna diagnoza prenatalna: dylemat rodziców, wyzwanie dla profesjonalistów, http://www.mp.pl/etyka/poczatki_zycia/39622,niepomyslnadiagnoza-prenatalna-dylemat-rodzicow-wyzwanie-dla-profesjonalistow [dostęp: 2.05.2017].

Korzeniewska-Eksterowicz A. i in. (oprac.), Standardy prowadzenia pediatrycznej opieki paliatywnej Ogólnopolskiego Forum Pediatrycznej Opieki Paliatywnej, http:/ / ofpop. pl/wp-content/themes/inove/img/standardy-ofpop-2016.pdf [dostęp: 29.04.2017].

Krzeszowiak J., Śmigiel R., Rola i zadania położnej jako członka zespołu sprawującego opiekę nad ciężarna pacjentka z rozpoznana wada letalna u płodu, „Pielęgniarstwo i Zdrowie Publiczne" 2016, 6, 1.

Kypros H., Nicolaides P., Węgrzyn P., Badanie ultrasonograficzne między 11+0-13+6 tygodniem ciąży, Fetal Medicine Foundation, London 2004.

Libera A., Psychologiczny aspekt poronień, [w:] Psychologia w położnictwie i ginekologii, red. M. Makara-Studzińska, G. Iwanowicz-Palus, Wydawnictwo Lekarskie PZWL, Warszawa 2009.

Łuczak-Wawrzyniak J., Leczenie jest sztuka- na pod-stawie wybranych obszarów działalności szpitala ginekologiczno-położniczego, „Ginekologia Polska” 2002, nr 73(10).

Makselon J., Typologia $i$ dynamika żałoby, [w:] Człowiek nieuleczalnie chory, red. B. Block, W. Otrębski, WNS KUL, Lublin 1997.

Maksiewicz D., Dangel T., II Ogólnopolska Konferencja Hospicjów Perinatalnych, „Hospicjum" 2015, nr 2 (72), file:///C:/Users/aneta/Downloads/informatorhospicjum-nr72-czerwiec-2015\%20(1).pdf [dostęp: 9.05.2017].

Rozporządzenie Ministra Zdrowia z dnia z dnia 9 listopada 2015 r. w sprawie standardów postępowania medycznego przy udzielaniu świadczeń zdrowotnych w dziedzinie położnictwa i ginekologii z zakresu okołoporodowej opieki położniczo-ginekologicznej, sprawowanej nad kobieta w okresie ciąży, porodu, połogu, w przypadkach występowa- 
nia określonych powikłań oraz opieki nad kobieta w sytuacji niepowodzeń potożniczych (Dz.U. poz. 2007).

Rozporządzenia Ministra Zdrowia z dnia 6 listopada 2013 r. w sprawie świadczeń gwarantowanych z zakresu programów zdrowotnych (Dz.U. 2013, poz. 1505).

Rozporządzenie Ministra Zdrowia z dnia 20 września 2012 r. w sprawie standardów postępowania medycznego przy udzielaniu świadczeń zdrowotnych z zakresu opieki okołoporodowej sprawowanej nad kobieta w okresie fizjologicznej ciaży, fizjologicznego porodu, połogu oraz opieki nad noworodkiem (Dz.U. z 2016 r. poz. 1132).

Skrzypczak J., Kornacki J., Ciaża o przebiegu niepowikłanym, [w:] Położnictwo. Podręcznik dla położnych i pielęgniarek, red. G.H. Bębrowicz, PZWL, Warszawa 2005.

Szpital to nie jest dobre miejsce dla dzieci. Rozmowa z Tomaszem Dangelem, „Hospicjum" 2011, nr 1 (55), file:///C:/Users/aneta/Downloads/informator-hospi cjum-nr55-marzec-2011.pdf [dostęp: 21.02.2017].

Szymkiewicz-Dangel J., Perinatalna opieka paliatywna- czy możliwa jest wspótpraca położników i neonatologów z hospicjami domowymi dla dzieci?, „Opieka Paliatywna nad Dziećmi" 2007, t. 15.

Wysocka-Pleczyk M., Grupy wsparcia online jako nowa forma pomocy w zmaganiu sie $z$ choroba, „Hygeia Public Health” 2012, 47 (4).

Zarządzenie Nr 66/2007/DSOZ Prezesa Narodowego Funduszu Zdrowiaz dnia 20 września 2007 r. 